\title{
BEAT WOMEN POETS AND WRITERS: COUNTERCULTURAL URBAN GEOGRAPHIES AND FEMINIST AVANT-GARDE POETICS
}

\author{
ISABEL CASTELAO-GÓMEZ \\ National Distance Education University (UNED) \\ icastelao@flog.uned.es
}

\begin{abstract}
The work of Beat women poets and their contribution to the Beat canon was neglected for decades until the late nineties. This study presents a critical appreciation of early Beat women poets and writers' impact on contemporary US literature drawing from theoretical tools provided by feminist literary and poetry criticism and gender studies on geography. The aim is to situate this female literary community, in specific the one of late 1950s and 1960s in New York, within the Beat generation and to analyze the characteristics of their cultural and literary phenomena, highlighting two of their most important contributions from the point of view of gender, cultural and literary studies: their negotiation of urban geographies and city space as bohemian women and writers, and their revision of Beat aesthetics through a feminist avant-garde poetics.
\end{abstract}

Keywords: Beat women, women's poetry, avant-garde poetics, feminist criticism, feminist geographies. 


\title{
MUJERES POETAS Y ESCRITORAS BEAT: GEOGRAFÍAS URBANAS CONTRACULTURALES Y POÉTICA FEMINISTA AVANT-GARDE
}

\begin{abstract}
RESUMEN. El trabajo de las mujeres poetas Beat y su contribución al canon Beat fue desatendido durante décadas hasta el final de los noventa. Este estudio presenta una apreciación crítica del impacto de las mujeres poetas y escritoras Beat en la literatura contemporánea estadounidense desde las perspectivas teóricas de la crítica feminista literaria y los estudios de género sobre espacio geográfico. El objetivo es situar esta comunidad literaria femenina, en particular la del final de los cincuenta y década de los sesenta en Nueva York, en relación a la generación Beat y analizar las característica de su fenómeno cultural y literario subrayando dos de sus contribuciones más importantes desde el punto de vista de los estudios de género, literarios y culturales: la negociación con la geografía urbana y el espacio de la ciudad como mujeres bohemias y escritoras, y la revisión de la estética Beat a través de su poética feminista avant-garde.
\end{abstract}

Palabras clave: Mujeres Beat, poesía de mujeres, poética avant-garde, crítica feminista, geografías feministas.

Received 15 June 2015

Revised version accepted 18 February 2016

\section{LITERARY COMMUNITIES}

In the brief period of a year and a half there have been two important publishing events that have undoubtedly called the attention of any Beat and U.S. women's literature scholar. The most important is the publication of Elise Cowen's poetry anthology Poems and Fragments (2014). Cowen was a New York Beat woman poet forgotten in the Beat canon whose poetry has been lost in the limbo of authorial rights since her death by suicide in 1962. Hers is one of the most enigmatic and richly textured poetry of the Beat women poets' oeuvres, but, although academic studies on some of her poems have come out during the years, the compilation and edition of her surviving poetry was not released until recently by Cowen scholar Tony Trigilio. The other important event I refer to - although national in scope - is the translated anthology of Beat women poets into Spanish Beat Attitude: Antología de mujeres poetas de la generación beat (2015) by the hand of the independent press Bartleby Editores. An introduction of these authors to the Spanish readers that was clearly overdue.

The study developed here addresses an academic national and international neglect regarding Beat women poets and writers, with the exception of the studies of the late nineties that will be detailed further on. The first section intends to 
outline the characteristics of their Beat literary community in general terms and their position and role as women within it. The following two sections will focus on what I think constitutes Beat women writers and poets' most outstanding contributions to women's cultural history and literature in English: their negotiations of urban geographies from a countercultural ideologically and aesthetically stand as women - detaining on the New York bohemia geographical locus - and the practice of a contemporary feminist avant-garde poetics whose foundations would influence, I think, most of women's feminist experimental poetry in English since then. Regarding this point, I will focus on early or secondgeneration Beat women poets from New York in order to critically outline their diversions from masculinist Beat aesthetics.

We should start by considering that the Beat generation is a loose term that originated in a close nucleus of intellectuals in the late 1940s New York and ended up representing the spirit of the countercultural movement throughout the 1960s with a bicoastal focus - New York and San Francisco. "There has been considerable confusion about the term, as well as the word 'beat' itself, but there is no disagreement that there has been a phenomenon known as the Beat Generation writers," says Beat critic Anne Charters (1992: xvi). This phenomenon, however, started as the Romantic heroic outlawed restlessness of a small group of young - male - university students: Allen Ginsberg, Jack Kerouac, Lucien Carr, William Burroughs and John Clellon Holmes, who discussed in Time Square's cafes about the sense of the term beat in a post-World-War II American scene. The word first related to jazz meaning "down and out, poor and exhausted" and to hustlers' slang suggesting "at the bottom of the world, sleepless, wide-eyed, rejected by society, on your own, streetwise" (Ginsberg in Charters 1992: xviii), both meanings fitting the young group's sense of weariness and frustration with a lethargic and conservative Cold War American society. Beat acquired a literary and cultural meaning of existential melancholy not devoid of an experiential avidity for change, a new consciousness and a new attitude towards reality and the artistic experience. They defined their own philosophy through novels and articles, but there were clearly two events that launched what had been the illuminations of a small group of young male intellectuals into public awareness: the publication of On the Road by Kerouac (1957) and the mediatized trial against obscenity for Howl and Other Poems by Ginsberg in San Francisco that same year.

We can consider the date of 1959, crowned by Kerouac's article "The Origins of the Beat Generation", as the point where Beat stopped being the label of a small artistic and hipster American bicoastal community to represent a more inclusive American bohemian rebellious youth: 'When the term 'Beat Generation' began to 
be used as a label for the young people Kerouac called hipsters or beatsters' in the late 1950s, the word 'beat' lost its specific reference to a particular subculture and became a synonym for anyone living as a bohemian or acting rebelliously or appearing to advocate a revolution in manners" (Charters xxii). It is in the late 1950s and 1960s when most of the writing by Beat women took place. In the late 1960s, Beat inevitably transformed itself into the hippie culture as the new phenomenon of American counterculture ${ }^{1}$.

I would like to detain on the most influencing gathering of East and West Coast Beat writers and thinkers, in order to fanaticize about the position and role of women in it. The "Six Poets at the Six Gallery" reading in San Francisco in 1955 was where Allen Ginsberg, invited by Kenneth Rexroth and accompanied by other Beat poets, read for the first time the poem "Howl". An audience of about hundred and fifty artists, writers and bohemians in the Six Gallery, according to Michael McClure, shared a common awakening and awareness in this poetic session that materialized the culturally and politically assertiveness of a new spirit of rebellion and individual freedom. McClure's remembrance of the event states:

As artists we were oppressed [...] We saw that the art of poetry was essentially dead-killed by war, academies, neglect [...] We wanted to make it new and we wanted to invent it. We wanted voice and we wanted vision [sic]. [...] At the deepest level [we realized] that a barrier had been broken, that a human voice and body had been hurled against the harsh wall of America. (in Charters xxviii)

Where were the Beat women in the Six Gallery that night? They must have been sitting in the audience as companions, friends, lovers, supporters, many probably writers and artists too, but as Hettie Jones - herself writer, poet, coeditor of the independent press Yugen together with her husband, the Beat AfroAmerican writer LeRoi Jones - writes in her memoir How I Became Hettie Jones: "I was too ashamed to show [my poems]. I didn't like my tone of voice, the twist of my tongue. At the open readings, where anyone could stand up, I remained in the cheering audience" (in Friedman 1998: 234). Part of the issues this paper would like to address are the ones hidden behind the fact that women were an invisible presence in events like the Six Gallery reading - a presence not worth paying attention to in cultural or literary history until the late nineties.

\footnotetext{
1 Beat philosophy and aesthetics originated in New York bohemian community, but soon searched alliance with other West Coast intellectuals and poets belonging to what has been called the San Francisco Poetry Renaissance. Beats belonged to a plural scene of American experimental poetics practiced in the 1960s also by Black Mountain poets and New York School poets - what Donald M. Allen called "the New American poetry".
} 
One of the most obvious reasons, well-founded by feminist work done from then on, is summarized in the straightforward statement that opens one of Roseanne Giannini Quinn's articles on Diane di Prima: “The Beat literary movement can safely be described as masculinist" (2012: 19). Another is that - As Jone's words let us see - part of the motivation for choosing minor characterization, alluding to the ironical title of Joyce Johnson's memoir about precisely this second league of women cohorts and writers of the Beat generation, came from these women's lack of sophisticated feminist intellectual tools to explain and understand how their literary productions and bohemian lives as absent presences in the community were strategically and culturally subversive within and beyond Beat rebellion.

The Beat women listeners at the Six Gallery surely shared many of the elements that constituted Beat attitude: disenchantment with the current American way of life based on materialism, dullness of spinit and conformism; furtiveness and vitalism that searched for experience on the move; experimentation with selfhood and art; introspection that looked for definitions of identity that relied on spontaneous writing, public reading, collaborative work and street and intellectual community bonding. And they were probably also keen to be influenced by the enthusiastic message of possibility and revelation from Ginsberg's collective performative event. But their cultural and historical moment, their psychological and material foundations to understand and practice this ethos had specific differences in relations to their male colleagues due to gender. Beat femaleness deserves attention because it inevitably diverges from male Beats' practices and theories due to cultural and historical factors.

Studying women Beats' lives and work we are opening the defining sphere of the Beat literary community and reinscribing the term Beat within a wider representation of its practices, discourses and spirit, breaking up a monolithic masculinist definition of the movement and the community in literary and historical terms. The sense of community is important for the understanding of the Beat phenomenon and the role of women in it. As we have seen, Beat premises and philosophy were triggered by a close sense of male companionship in which homosocial and sexual ties were central. Although the later expansion of the Beat community includes women, it is undeniable that the basic precepts of Beat ethics and aesthetics are originally masculine: including male-bonding, the influence of Romantic heroism and male American Transcendental writers, the importance of individual freedom and unattachment to domesticity or everyday life. Beat feminist scholar Ronna Johnson considers that:

Beat bohemianism situates the individual as an artist, usually male, in opposition to bourgeois culture. [...] It promulgates political and aesthetic dissent through 
transgressive behaviors accentuating poverty, excess, youth, and the tribe. [...] through the energy and sanctuary of bars, cafes, hotels, pads, and the street life they were able to negotiate and reinterpret the realities of postwar American life. (in Grace and Johnson 2004: 47)

Female bohemianism had to find other Beat community bonding among women since within the mainstream Beat literary community women were supposed to "say nothing and wear black", if we take Jack Kerouac's definition of female companionship to male cool hipsters (in Johnson and Grace 2002: 1). Women Beats were not absent in the scene but, as Johnson puts it, elided by official male histories of the community, transforming their roles into marginal ones (2004: 5). They, however, in relation to the early Beat community in New York, inhabited the East Village and cheaper Lower East Side from the beginning. Diane di Prima says in an interview: "We made the community, there was no community before. When I hit the Lower East Side in 1953, they thought I must be a whore because women didn't live alone, and then slowly, you found a few other people doing the same thing in other areas" (in Grace and Johnson 2004: 89).

Regarding the way they supported each other as a female literary community within the male leading artistic community we find different perspectives among critics. Amy L Freidman considers that female support existed in sharing the conflicts between everyday tasks as mothers and lovers of men and their work as artists, writers and editors of independent presses (1998: 239)2. While Johnson and Grace considers that, in contrast with male authors' safe and constant support by other male partners for whom "commitment to collaborative work was intense" (Elkholy 2012: 3), Beat women authors often felt isolated in their growing-up as women poets (Johnson and Grace 2002: 17). What is obvious is that as protofeminists they could not reach the cultural impulse to create a community based on sisterhood, characteristic of a posterior second-wave feminism, that would encourage their work, and it seems that most of them chose to regard themselves as solitary questers, isolated female figures within the male main group, and almost always as companions and sexual partners of male Beat writers - e.g. di Prima and Jones mamied LeRoy Jones, Johnson dated Kerouac, Cowen dated Ginsberg.

The biased gendered agenda of the movement was unveiled in the late nineties through groundbreaking gynocritical feminist work that unearthed forgotten Beat female figures. The maleness of the philosophy and tenets of Beat

Friedman's article focuses on Beat women writers' contributions as editors of independent presses. She informs us about Hettie Jones being co-editor of the magazine Yugen and Diane di Prima being co-editor of the experimental poetry magazine The Floating Bear. 
cultural space is so deeply established that before these critical works women Beats were totally absent from feminist poetical anthologies and critical works ${ }^{3}$. This is why the importance of the following works, to which I will devote a brief description, cannot be underestimated.

Women of the Beat Generation (1996) by Brenda Knight is the first serious study of Beat women. It reached significant media attention and it is now considered a landmark in Beat scholarship. The book is divided in four parts devoted to early precursors - i.e. Helen Adam, Jane Bowles, Madeline Gleason muses or Beat writers' wives - i.e. Joan Burroughs, Carolyn Cassady, Joan Kerouac, or Eileen Kaufman - writers - i.e. fifteen in total including Mary Fabilli, Diane di Prima, Denise Levertov, Elise Cowen, Joyce Johnson, Hettie Jones or Joanne Kyger - and Beat women artists. A Different Beat (1997), edited by Richards Peabody, is the first anthology of writings by women of the Beat generation. The work chosen is up to 1965 and includes many of the authors in Knight's book and others very little known for which this anthology gains important credit - i.e. Carol Bergé, Sheri Martinelli, Barbara Moraff, or Margaret Randall among others. Girls Who Wore Black (2002), by Ronna Johnson and Nancy Grace, is the first edited volume on Beat women writers with articles that bring academic emphasis on their two major genres: life writing and poetry. These scholars later edited Breaking the Rule of Cool (2004), a volume that includes an important introductory article by Johnson and a collection of interviews to several Beat women writers. These works opened the venue to rewrite Beat literature from a female Beatness, studying the contributions of writers and poets such as ruth weiss, Lenore Kandell, Anne Waldman, Joanne McClure, Mary Norbert Körte, Sandra Hochman - not mentioned above - among many others.

According to Johnson, there is a first-generation Beat women writers, born in the 1910s and 1920s, who were contemporaneous with Kerouac, Ginsberg and Burroughs, who lived the traumas of World War II and whose poetics departed from the main precept of confessional spontaneity towards a more direct negotiation with experimental modernism (2004: 8-9). Within this group she includes Madeline Gleason, Helen Adam, Sheri Martinelli, ruth weiss, Carol Bergé, Jane Bowles and Denise Levertov.

A second-generation of women Beat writers was born in the 1930s, being directly influenced by main male Beat canonical figures since they were a decade

\footnotetext{
3 No Beat author is included in No More Masks: An Anthology of Twentieth-Century American Poets (1993) or Coming to Light: American Women Poets in the Twentieth-Century (1985), and only di Prima shyly appears in the late edition of the classic The Norton Anthology of Literature by Women.
} 
or more a younger generation. However, this second-generation was little influenced by women Beat writers of the first-generation. This group of writers produced the most important body of work in order to analyze a specific female Beat aesthetics. Being the most representative of an early proto-feminist Beat ethos, this study refers mostly to them by date and period. They were more feminist oriented, clearly influencing the second-wave feminist movement, since they were conscious of their countercultural choices of lifestyles that subverted the 1950s and early 1960s American social expectations regarding femininity. But most importantly, they were starting to be aware of the marginalization that their male partners forced on their creative potential. They appropriated Beat myths and ethos to reformulate them from a female perspective: for example, noncomformity was translated into women's sexual freedom; mobility for them, more than on the road, focused on leaving the suburbs and moving into independent life in the city (an aspect studied in detail in the second section of this paper); the Romantic ideal of detachment, refusal to commitment and dark heroism was radically transformed into an integration of everyday life, maternity and domesticity into Beat aesthetics (which will be the focus of the third section). Second-generation Beat bohemian women were highly experimental in life and art, and an important point that they had in common was that most of them had had access to higher education, as the first novel on Beat female heroism, Come and Join the Dance by Joyce Johnson (1961), shows. Among this group Johnson includes Joanne McClure, Lenore Kandel, Elise Cowen, Diane di Prima, Hettie Jones, Joanne Kyger, Joyce Johnson, Ann Charters - the first literary critic in the community - Brenda Frazer, Margaret Randall, Diane Wakoski, Barbara Moraff, Rochelle Owens and Carolyn Cassady, among others.

A third-generation Beat women writers, born during the war and growing into writing in the 1960s, had a defined feminist consciousness and assimilated the female Beat ethics and aesthetics into the countercultural hippie revolution. They were clearly influenced by previous female Beat writers' generations and had solid awareness of public authorial assertiveness and female creative potential. They also enjoyed a greater equality between men and women in the group. In this group Johnson includes Janine Pommy-Vega - although her Poems to Fernando share many of the elements of second-generation women's poetry Anne Waldman, Patti Smith, and Laurie Anderson.

To close this section I would like to address how Jan Montefiore in Feminism and Poetry (1987) suggested a new turn for feminist literary criticism to think about the nature of female literary traditions, especially in poetry. She critiqued American feminists such as Gilbert and Gubar for foregrounding the idea that 
women's writing as tradition is founded on the element of ambivalence towards creation. This approach would be difficult to apply to Beat authors since they had a proto-feminist spirit and a wish to write as women. She also brought a critique on Adrienne Rich's idea of women's writing creating tradition through the strength of supportive collectivity and solidarity between women. Beat women seemed to lack this support, as it has been previously stated in the study; according to Johnson and Grace, "This reality differs dramatically from the experiences of the male Beat writers, whose community of support was tightly knit" (2002: 17).

Montefiore's study includes a third founding element for the construction of a female poetic tradition: the playful and contingent negotiation with a - usually male - poetic tradition. This, as we will see in relation to Beat women's feminist avantgarde poetics, should be taken, I think, as a central issue for female Beat poets, since they constantly negotiate with Beat precepts, attitude, ethics and aesthetics, from which they write but which they transform singularly in their poetry.

This in-betweeness, this experimentalism within experimentalism in an artistic and literary community may remind us of another literary community of women that shared not only the same struggle against the foundations of male avantgarde aesthetic principles, but also the same geographical locus (New York) for their rebellion as insiders: the women writers of the avant-garde Modernist movement in the 1910 and 1920s, who also placed their bohemia in Greenwich Village. However, there has been given little critical attention to the connection of these two women's groups, which would deserve a whole article.

The Beat women writers of the second-generation constituted, to my view, a community within the Beat literary community, joined by a Beat and female cultural and literary counter-tradition that interestingly transformed and appropriated Beatness to expand its meaning and practices.

\section{COUNTERCULTURAL URBAN GEOGRAPHIES}

The history of the women poets and writers of the Beat literary community in New York in the 1950s and 1960s is a story of a paradoxical and simultaneous presence and absence in place and a story of the power of poetic space to redefine cultural and real space for women. The next two sections will analyze these two premises in relation to Beat women poets and writers' occupation of urban space and to their practice of an avant-garde feminist poetics. My aim is to allow a redefinition of Beat where feminism and women have a place, a metaphorical and physical space as inhabitants of bohemia and the urban environment. 
Cultural critic Janet Wolff has studied the importance of space, the specific urban locus of New York Greenwich Village and the concepts of movement and travel for the Beat generation from the point of view of gender. Studying American culture in the fifties, she writes about the importance "of the altemative cultures for young women independent enough to look for ways of escaping the suburban idyll. Greenwich Village figures large in these escape scenarios, as a symbolic and actual place for possibilities of a different life" (1995: 141). Considering that the countercultures of the time were "male, sexist and most often sexually reactionary", women arriving to their urban experience found themselves facilitators of men's dreams more than "equal participants in personal and social transformation" (1995: 143). A quote Wolff utilizes to exemplify this minor characterization of women Beat in the urban bohemian scene, taken from Alix Kates Shulman's novel Burning Questions is revelatory: "They [men] carried slim notebooks in their back hip pockets to scribble in as they sat in their favorite café night after night [...]. They acted as if to belong they had to open their notebooks; but we [women] had to open our legs: for us, art talk and scribbling were considered pretentious" (1995: 142).

Wolff also studies the relation of women writers to the Beat dream of "travelling on the road" over which Joyce Johnson reflects in her Minor Characters memoir: "In 1957, Jack [Kerouac] was still traveling [...]. He would leave me very soon and go to Tangier... I'd listen to him with delight and pain, seeing all the pictures he painted so well for me, wanting to go with him. Could he ever include a woman in his journeys?' (1995: 121). Wolff considers that nomadic subjectivity and identity on the move has been an experience of liberty culturally established as male in Western history, since "women have never had the same access to the road" (1995: 121). Although I would like to devote this section more to the symbolic and material consequences of women Beat's occupancy of urban space, a brief reflection on movement, Beat and gender must be posed in order to contrast the fact that while masculinist Beat Romantic myths of liberty included travelling away from home, Beat men hardly paid attention in their literature to the importance of rebellion found in the act of women leaving the suburbs and home to move (culturally and physically) to the city as Beats, which most of them did. Diane di Prima left her Italian-American Brooklyn home to head the Lower East Side, Pommy-Vega dropped school and left New Jersey, Joyce Johnson left college and parents, as many others.

The field of feminist geographies provides valuable tools to understand how important the reconfiguration of space is for feminist purpose. It constitutes the proper theoretical framework to study not only the meanings implied in Beat women's reconfigurations of space and gender, but also the reasons hidden behind 
Beat men's understanding of travelling and movement as a solely masculine practice and symbol of freedom from family ties and attachment to women.

Feminist geographers such as Doreen Massey, Linda McDowell or Gillian Rose started studying the interrelation of space and gender in the mid-nineties. They studied how gender identity is established through space and how environment and space are envisioned, constructed and used from gendered positions and perspectives. They also studied in detail why certain notions and cultural spatial practices are assigned to men or women and how to transgress established spatial divisions that enclose women in the private sphere and men in the public space and in mobility. Through these two decades they have studied these issues dividing research into geographical scales such as natural and built environments, globalism/locality, national spaces, city and urban studies, neighborhoods, and the body.

Doreen Massey echoes other geographers' views in the assertion about "the masculine desire to fix the woman in a stable and stabilizing identity" (1994: 11) and in the encouragement towards women's mobility to transgress this symbolic cultural stagnation of the feminine. "From Victorian Lady Travellers", Massey insists, "women have had to leave home precisely in order to forge their own version of their identities" (ibid.). Linda McDowell considers it is necessary nowadays to take into consideration geographies of gender as a constitutive field for feminist thought, she describes that the aim of feminist geography is "to investigate, make visible and challenge the relationships between gender divisions and spatial divisions [...] to examine the extent to which women and men experience spaces and places differently and to show how these differences themselves are part of the social constitution of gender as well as place" (1999: 12). In relation to these differences, Gillian Rose's thorough study of geographical knowledge and gender - highly philosophical in its theses - concludes with a view particularly revelatory for our study that places men's gaze in space as the pressure that has historically positioned women as located in space and with a specific sense of spatial embodiment. She considers that feminine subjects constitute themselves "through an intense self-awareness about being seen and about taking up space [...]. Unlike men who believe they can transcend the specificities of their body", perceiving somehow spatial reality as transparent geography (1993: 143).

The Beat women poets and writers of the New York's bohemia that moved to the East Village and Lower East Side as early Beats were simultaneously invisible as women in the city and bodily present as feminist bohemians. The interstice created by this countercultural gendered urban geography helped to reconfigure and 
rewrite the relation of women artists to urban space and place. Therefore, early Beat women's history should be analyzed focusing on the spatial scale of the city and the body; the embodiment of the city. Feminist architect Dolores Hayden studies how in the late 1940s in the United States "the single-family home was boosted, and the construction of isolated, overprivatized, energy-consuming dwellings became commonplace" (2000: 268). Women during the 1950s suffered, as Betty Friedan reflected in her classic book, the Feminine Mystique, a middle-class suburban malady of isolation, becoming also the target of the consumption market in their domestic roles. Second-generation Beat women writers on the East Coast who moved to Lower East Side New York and Greenwich Village became bohemian city dwellers, charging the city as political locus against patriarchy and capitalism and choosing the city as utopian place to construct their identities as women artists. Spatial philosopher Elizabeth Grosz considers bodies and cities construct each other through the production and circulation of power dynamics (1992: 250). Thus, cities can be seen as particular enabling places for the transformation of political, social and cultural power by groups of people who can transgress and redirect this dense circulation of power and control strategies on society. Beat artists took over the city streets as new countercultural dwellers and made public, through spontaneous readings or slam poetry sessions in cafes and in the streets - or simply by being and taking space - their non-conformist ethics and aesthetics. Women were there but were hardly seen, although their taking over of the city streets was probably the most subversive political act of all Beat enactments.

The invisibility and visibility of women in the modern city and in the street have been thoroughly studied by feminist geographers and critics of architectural space. The figure of the female flâneur - i.e. anonymous city stroller, contemplative observer of street life - has always seemed problematic and called the attention of these critics because the moment the city becomes an object of observation, of pleasure and inspiration, the stroller or observer must become the subject of the gaze: a position of power that generally excludes women. According to Jane Rendell "for artists and writers, from romanticism, to Dada, [...] to contemporary work, urban roaming, drifting and flânerie has defined a particular approach to creative practice" (2002: i). In the case of Beat bohemia, inhabiting those specific New York neighborhoods and also the mobility and agency through the city space and street life was what provided with the spatial reality for action and the imaginary realm for their aesthetics. Although conceptualized abstractly as feminine, due to its threatening disorderly or laberynthic nature, the modern city has been a space designed for masculine experience and restricted to women as possible inhabitants or ludicrous visitors. Elizabeth Wilson's groundbreaking study of the city and women, The Sphinx in the City, suggested that the experience of 
the modern city provided women with a space of freedom to be, to get lost, and to experiment in, and that the visibility of women as urban strollers and inhabitants should be claimed from a feminist perspective. Her thesis challenges other feminist cultural critics that consider that a subject position as flâneuse is not possible for women due to the materiality - and position of objectification - of their bodies that renders them visible as space itself but invisible as subjects. After thinking about the gender dynamics of space, Jane Rendell states that "men own and occupy spaces and women are space" (2002: 4). My view is that, on the one hand, early Beat women transgressed the stablished spatial patriarchal nature of gender differentiation by moving into the city: the separation of male (public) and female (private) spheres goes hand in hand with the development of the modern city, but they used the city bohemia to become presence in the same modern city that wanted to exclude women. On the other hand, my opinion is that Beat women reinscribed their modern countercultural proto-feminist and female subjectivities "being" space - paradoxically being body and therefore materially visible but also individually invisible as subjects - and "owning and occupying" space as women in a different way as men did, since they lived across the private and the public, the domestic and the artistic, in the same way as they ran independent presses but were also silent. They were flâneuses that observed as subjects, and dwellers that lived the city as women artists.

Their experience would be a living example of a "politics of paradoxical space" that according to Gillian Rose becomes the best practice of a feminist subjectivity regarding the geographical knowledge of the extreme spatial division or binary of public and private (mind/body, culture/nature, etc.), in which patriarchal power has enclosed women and men. A space that is "multidimensional, shifting and contingent. It is also paradoxical, [so] spaces that would be mutually exclusive are occupied simultaneously" (Rose 1993: 140). This simultaneous in and out, or inbetween position in spatial dynamics and practices renders Beat women poets and artists' countercultural urban geographies politically subversive and culturally meaningful. A similar conclusion regarding the possibility of transgressing gendered spatial dynamics is considered by Doreen Massey who encourages women to move away from home but also highlights the need to keep an awareness of situatedness: "the challenge is to achieve this whilst at the same time recognizing one's necessary locatedness and embeddedness/embodiedness, and taking responsibility for it" (1994: 11). Janet Wolff also warns women against a masculinized type of liberty as "ungrounded and unbounded movement"; she says that the "suggestion of free and equal mobility is itself a deception [since] destabilizing has to be situated" (1995: 128). Beat women seemed to understand this simultaneously paradoxical appropriation of space and positions since they were women artists - itself a 
complicated and contradictory identitary definition - and they managed to be poets, lovers, mothers, wives, and writers in the Beat community.

Feminist philosopher Elizabeth Grosz enables us to redefine early Beat women as important pre-feminist precursors, since by their appropriation of the urban, and also an experimental poetic space to which next section will be devoted, they denounce "men's invasion and occupancy of space as their own and "were able to experiment with and produce the possibility of occupying, dwelling, or living in new spaces, which in their turn help generate new perspectives, new bodies, new ways of inhabiting" (2000: 221).

For Beat men, the city became a prelude to the road, mobility and freedom in the city as flaneurrs shared the same ethos of rejection to commitment and family life as their road trips, they avoided women as travelling companions because they were reminders of stasis and attachment. Women, on the other hand, by moving into and in the city bohemia broke up with the ideology and politics of the division of different spheres putting into practice a reconceptualization of space from their own perspective, relying on this environment to create themselves as women and artists and challenging the cultural prohibition, greatly emphasized in the 1950s, of women as moving subjects and city dwellers.

Beat women artists and poets did not erase the private in order to occupy the public but negotiated with both spheres erasing a clear division between them, a liminality also represented in their poetics. This is probably their greatest spatial and poetic feminist achievement. They flied and stayed, they moved and remained, they filled the bohemian street with strollers and struggled to join maternity and creativity, they opened private rooms and beds towards the street, they talked with a public Beat voice about nappies or menstruation, and they wrote of the intimacy of bodies and love through street language.

They dwelled the city as they dwelled poetry. And they mastered the art, as Johnson suggests, of in-between (2004: 21).

\section{FEMINIST AVANT-GARDE POETICS}

Having analyzed the social and cultural implications of Beat women's move to the city of New York as bohemians, I will now foreground the elements and characteristics of their Beat poetry - with special emphasis on second-generation New York poets - that were responsible for what Brenda Knight and other critics consider to be a revolution that changed forever the perception and praxis of poetry, and consequently of contemporary American literature (1996: 2). My 
interest will lie in defining the premises of a Beat avant-garde poetics that women Beat poets shared and outline the extensions and transformations of this Beat aesthetics in their own feminist avant-garde poetic practice.

Elisabeth Frost, in her book The Feminist Avant-Garde in American Poetry, suggests that theoretical intersections between feminism and avant-garde aesthetics in literature have been generally neglected throughout the last century, and it has been certainly the case for Beat women's poetry (2003: xiv) ${ }^{4}$. However, her definition of avant-garde: "an artistic practice that combines radical new forms with radical politics", "that unites formal innovation with political engagement" (2003: xiv) is useful to apply to Beat women poets; as well as her differentiation between the adjectival terms experimental, innovative or avant-garde writing. In the case of the Beats, avant-garde would sound the most appropriate not only because they act as early vanguard of following political and literary experimentation in the seventies, and in the case of Beat women of second-wave feminist revolution, but also because of their relation of tension with the historical modernist avant-gardes of previous generations, which for women Beats in particular was more intense than for men Beats, who moved towards negotiations with Romanticism, as we will shortly analyze.

Above all, I would claim the inclusion of female Beat poets within the group of other experimental avant-garde women writers before them - Futurist, Surrealist, and other modernist avant-gardes - because they share the same characteristic ambivalent relation of "alliance and divergences from those movements" that other previous women had with their "male avant-gardist rhetoric of revolution", which was installed in the innovative groups they belonged to as exclusively distinctive (Frost 2003: xii-xiii). Other characteristics that can be added to the definition of avant-garde are their structural social formation as groups of people or movements that create a specific corpus of social events and literary work; and according to Maria Damon, the intention to drag poetry and artistic praxis from contemplation and meditation towards more instant creative ways of production in which culture relates more closely to the everyday (2009: 10).

A definition of Beat aesthetics derived from real artistic and literary production needs a flexible and inclusive terminology, because as Johnson and Grace rightfully state "Beat writing is stylistically and technically too diverse to constitute a homogeneous aesthetic or literary philosophy" (2002: 39). These two scholars define Beat style as: "spontaneous composition, direct expression of mind, no censorious revision, jazz-based improvisation; or factualism, cut-up, surrealism; or

4 Curiously enough, Frost herself does not mention them nor include them in her book. 
first-thought-best-thought, cataloguing pile-up images, following breath line, prophetic utterances" (2002: 2). While Knight provides this emotional definition: "Beat is underground, raw, unedited, pure, shocking. [... B Beat is an expulsion, a vomiting of vision" (1996: 5). On the other hand, Charters does not think Beats "shared formal aesthetic beyond their practice of experimental free-verse forms and their interest in poetry as performance". She considers more defining of their poetics on the one hand, the spatial urban geographical loci and the historical and cultural period that brought these people together, and on the other hand, their recognition of the "sanctity of individual experience" and the change of material medium for poetry from printing word to aural word/speech through radical politics and underground existential philosophy (1993: 589).

The specific Beat poetics of New York second-generation women poets drink from, but also transgress in their own way from a feminist perspective, the main precepts of a Beat literary aesthetics. I would like to focus on the elements of immediacy, orality and voice, the self-expression of a naked poetic I and prophetic vision in their poetry, which can be related to the complex ways these women negotiated their appropriation of the literary influences that male Beat poetics foregrounded as constituent of Beat aesthetics in relation to American avant-garde Modernism and Romanticism. As Johnson asserts, "they appropriated, transformed, and comected Beat discourses to inscribe their own subjectivity" (2004: 21).

Immediacy and orality are key aspects of Beat poetics as a way of turning away from an elitist modernist tradition of intellectualizing the work in print, and it is closely related to the appreciation of the poetic word as voice - public voice - and not as printed artifact. Voice as projection was present in Ginsberg's reading of "Howl", but Beat women's poems although read in poetry readings, or designed specifically as slam or jazz music, as is the case of West coast Beat poet ruth weiss, based themselves on more protected environments than the open public air. More than Judith Ginsbergs - alluding to Woolf's Judith Shakespeare we are more likely to find Dickinsonian hipsters in the corpus of secondgeneration Beat poets. There could be several reasons for the choice of taking the written page as performative space (Hunt 2002: 258), the most obvious is the difficulty to consider word as voice due to the voiceless existence women had experienced in literary history which Beat women writers also shared - as it has been argued in this paper. The other reason for choosing a private and written context for their poetic word is their explicit testament of being influenced by previous female literary and poetic traditions and modernist women and men poets - e.g. di Prima visited often Ezra Pound in Washington (Johnson and Grace 2002: 15). Another obvious reason is related to the issue of immediacy in contrast 
with a crafted poetics, well stated by Johnson and Grace: "they depart dramatically from what has become known as standard Beat poetics, the Kerouacian mandate for spontaneity [...] most women Beat writers revise their work; they are careful crafters of their texts" (2002: 16).

As an example we can read Diane di Prima's early poem "Minor Arcana", which is a crafted and contained brief poem that presents a poetic voice that summons her material body as place of belonging and origin of poetic voice. The poem itself becomes body for word in the material space of the page. The title symbolizes the reading of the secrets of the everyday, as the card of the minor arcana in tarot provides, through the undervalued mystery of the immediate body.

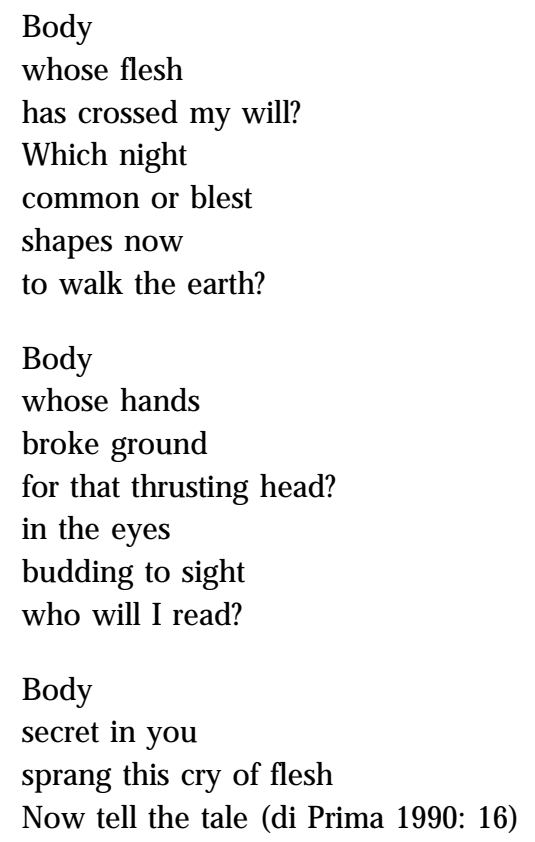

Beat women poets may share the use of spontaneous language but what we can clearly see in this poem, as in many others, is that poetic voice is materially cleaved to body and page. Words weigh in a non-transparent space as it is not projected towards the world but towards an intimate space of simultaneous expansion and containment. Diane di Prima, probably the most popular of Beat women writers, extremely prolific and outspoken as her life journey from an Italian American Brooklyn working-class home to the center of Beat New York bohemia shows, became assertively present in all venues of Beat gathering together with other male Beat poets from the late 1950s on. Although she uses 
flowing breath lines in some of her poems, most of her early ones resemble the crafted poetic strategies of the ironically titled "Minor Arcana".

Janine Pommy-Vega, a less known female poet younger than di Prima, who escaped from her New Jersey home and college graduation to rent a flat near Allen Ginsberg and Peter Orlovsky in the Lower East Side, was certainly more shy in her intent of being accepted within the community as writer. Her debut collection Poems to Fernando (1968) was published by City Lights in San Francisco after she came back from a trip around Europe where her husband, the Peruvian painter Fernando Vega, died of a heroin overdose. The love poems are dedicated to him but represent a journey of self-knowledge through the experience of love and travelling. They share an obvious open-form poetics of immediacy, since many of the poems describe foreign and New York landscapes, natural and built environments, through spontaneous perception and through poetic lines that scatter along the pages, but they are deeply intimate in their description of the love dances of the lyric voice. Written as a collection they were designed to be written word of reflection more than aural words for projection, revising the nature of the love lyric from a Beat aesthetics of urban, cosmopolitan existence.

Pommy-Vega's poem "Poem Against Endless Mass Poetry Reading" published as "Other Poems" within Poems to Fernando addresses the event of poetry reading as weakening the potential of poetic language for spiritual silence. It uses the same spontaneous open-form structure on the page as the love poems in the collection, highlighting the visual arrangement of lines more than their aural features to reach restoration and poetic peace from the "tyranny of assembled poets". This poem does not use voice as a unit of measure, thus duplicating its denunciation against the use of an unempathetic public voice as the unit of measure for Beat poetics, a voice that may ignore the reality of audience as real bodies and people in order to deliver its bodiless egocentric message.

$O$ the tyranny of assembled poets beleaguering ears \& the shoulder muscles

the blade cracks in my jaw \& the

head pangs.

Heavy underhanded deviousness

herding us in

\& cramming us with it $-[\ldots]$

\footnotetext{
5 It is important here to point out the differences found with the late poetry of third-generation Beat women - e.g. Anne Waldman, late work by di Prima - which moves towards visionary orality and becomes more expanded and spontaneous in form and content.
} 
O pay yr dues before ye lord it over

me,

Poets!

in silence/ the angels are breathing. (Pommy-Vega 1968: 48)

As Beat women poets dwelled the city, in and out, privately and publicly, they wrote their poetry. Beat women poets experimented with language and voice using Beat poetics but genderizing it, placing voice in the body and body in the word. Not only were their poems more carefully crafted, but their subject matter was also mostly gendered: female sexuality, maternity, the double bind of the woman poet. Surely enough they would not write a poetic I from an Emersonian "I am everything" and a Whitmanesque "I am everyone"; their avant-garde poetics shared a situated knowledge of the world, an embodied poetics that crossed boundaries between public and private spheres.

Tim Hunt's thesis considers that in following the influence of American Romantics, Beats were inserting in their aesthetics literary premises that belonged to a countertradition - the Transcendentalists - that "was itself already gendered" (2002: 256). The influence of Emerson's visionary experience through a "transparent eyeball" was exemplary for Beats, in the same way as the bardic orality of Whitman, a passionate immediacy connecting reader and poet. Hunt interestingly argues about the masculinist principles implicit in Emerson's visionary individualism: "It is worth remembering that the process that leads to his moment of vision erases all human connections and obligations, including those of family. [... ] It is a small step from this to a sense that commitments to others - specially sexual, domestic, and parental ones - preclude or compromise visionary experience" (2002: 256).

Female Beat poets experienced the world, the city and their subjectivity differently; female Beatness included connection, personal ties, the mysteries and ordinariness of the everyday and a very material perception of space and the body - either never transparent or avoidable. They marked gender on Beat poetry, talking about gender-issues that affected them, highlighting the complexities of femaleness and heterosexual relations, partly because one of their main poetic endeavors was to search self-definitions that imbricated femaleness and creativity putting their simultaneously being women and bohemian poets at peace.

Some did not succeed at this endeavor, being diagnosed with mental problems or committing suicide. Such was the case of Elise Cowen, whose poetry collection has just seen the light in 2014 by the editing effort of Tony Trigilio. Cowen's life was short and intense, being born in a Jewish-American family in Washington Heights she attended Barnard and met Leo Skir, Allen Ginsberg - who she dated 
briefly as part of Ginsberg's exploration of heterosexuality - and others; she shared apartment with Janine Pommy-Vega for a short period of time and was the lover of Carol Heller (Trigilio 2014: xiii). As Leo Skir reflects in "Elise Cowen: A Brief Memoir of the Fifties" she ran a chaotic Beat life getting in and out of depression, of existential melancholy and of different flats in New York bohemia (in Peabody 1997: 33). She seemed to give no importance to her writing - except for the fact that it was an intrinsic part of her everyday activity - and too much priority to her admiration towards Ginsberg. After going to California, becoming pregnant, having an abortion and finally losing her job in New York she suffered a psychotic breakdown and ended back in her parents' house from where she jumped out of the window (Skir in Peabody 1997: 40) ${ }^{6}$. Cowen's poems are a good example of how the domestic and the transcendental join in female poetic Beatness. Through her Dickinsonian detail to minute elements of the everyday, Cowen shows how cockroaches or oranges become worthy of Beat aesthetics, channels for connection with other beings or with the bodily weight of existence.

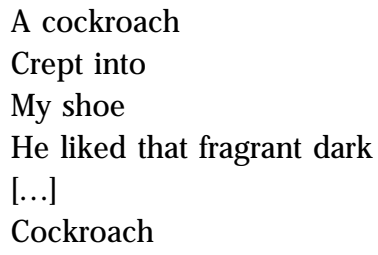

The best I can do for you Is compare you to bronze And the Jews

You're not really welcome to use my shoe

For a roadside $[. .$.

You've lost an antenna

I treat you

seriously affectionately as a child (2014: 15)

each orange is

heavy enough to crush a table

equal to its weight.

6 Her poetry, written in various notebooks, was destroyed by her parents except for a surviving notebook that Leo Skir rescued but never published (Trigilio 2014: xvi-xviii). 
tables solid water oranges naked

bodies goldfish bowl lost-gaping in orange horror

and green-moment drained of his ocean. [... ] (2014: 50)

Some other women succeeded in their search for self-definition as women and poets in the Beat community. This is the case of Diane di Prima, whose early poetry was strong and versatile; her voice used irony, street language and slang to mock coolness and elegantly hide anger, but also crafted containment, cryptic imagism and surrealism. Not only was she one of the first to give poetic voice to women in Beat circles describing how she joined parties, café readings or pad communal living, but also stating in her poetry how she perceived heterosexual relations, sexual liberty, the liberation from domestic roles from the point of view of a Beat woman, and what I think is more outstanding, how she managed to integrate maternity into bohemia ${ }^{7}$. As a pioneer in New York bohemia she wanted children but no men around, so had five from different partners including maternity as part of her artistic life in the city and later taking it to the road in the seventies ${ }^{8}$. Matemity was not an obstacle to reach Beat lifestyle for di Prima, it was a desired experience in order to become a Beat single-mother. "I Get My Period, September 1964" is a short poem that surfaces many issues in relation to maternity and heterosexual relations. It presents her failed maternal desire not through guilt but by denouncing the failure of her partner at making her pregnant and at connecting with another real and potential human being. She contrasts the public life of rebellion of her lover and the poor quality of his private domestic life through his lack of interest in interaction and love.

How can I forgive you this blood?

Which was not to flow again, but to cling joyously to my womb

To grow, and become a son?

When I turn to you in the night, you sigh, and turn over

When I turn to you in the afternoon, on our bed,

Where you lie reading, you put me off, saying only

It is hot, you are tired.

Differences with the Confessional women poets of the 1960s, who have generated much more critical attention than Beats, is that Beat women poets chose to bring the bedroom secrets to the public view moved by an ethics and aesthetics of rebellion that affected also their lifestyle and poetry.

8 A more detailed study of di Prima's maternal poetry and her experience of maternity in the Beat community can be found in Castelao-Gómez's article. 
You picket, you talk of violence, you draw blood

But only from me, unseeded \& hungry blood

Which meant to be something else.

The everyday of sexual relations, the ordinary life as women, the body and everyday objects as non-transparent but vortexes for poetic creativity, or genderissues such as sexuality and maternity are some of the ways many New York second-generation Beat women poets inserted domesticity into poetics; down-toearth visions far away from Transcedentalist masculinist precepts of mystical unattached individualism. Not so much bardic seers of the world from a transparent eyeball, as writers of body beats reacting to the world they lived at every moment as women, poets and lovers.

Talking about emotion, love, connectivity and relationships in their poetry was part of their particular view of the Beat ethos, breaking with this practice the dogmatic rule of Cool imposed by Beat men on their lifestyles and poetics. Being cool meant being autonomous, unattached, not depending on others, not showing weakness by creating or discussing emotional ties; within these masculinist views, women and emotional ties to women, represented home and stasis. Nevertheless, self-expression and self-knowledge in Beat women's poetry seems always to rely on connectivity and an attached naked I to others or to the material world. They were not afraid of an expressive poetic I or the display of feeling and emotion, understanding that evolution and inner movement could be achieved in harmony with a sense of home that meant commitment but not necessarily stasis. Johnson and Grace consider that: "For hipster women, the code of Cool duplicated female powerlessness and objectification, the gendered silence under the reign of which the majority of women of the 1950s suffered politically and socially" (2002: 8). Against this masculinization of the Beat community and language, di Prima wrote the ironic poem "Short Note on the Sparseness of Language", and anti-poem that mocks the way a poem should be under the rule of Cool that blocked expression of emotion and affective language.

wow man I said

when you tipped my chin and fed

on headlong spit my tongue's libation fluid

and wow I said when we hit the mattressrags

and wow was the dawn: we boiled the coffeegrounds

in an unkempt pot

wow man I said the day you put me down

(only the tone was different) 
wow man oh wow I took my comb

and my two books and cut and that was that

As a contrast, the major exponent of the expression of the emotion of lyricism and romantic love in female Beat poetics is Janine Pommy-Vega. This poet reinvented the love lyric in Poems to Fernando through a feminist avant-garde language that resembles, as Maria Damon asserts, the discourse of mystical love sieved through bohemian lenses; a love that includes the rhetoric of home as space of connection and belonging (2002: 205).
Here before the sunrise blue \& in this solitude to you: come home. The moon is full over morning buildings, the shade of solitude is upon my hand: Come home. In this empty loft of high windows the shades are lifting, and people are arrived; To you: in the early silence between us that IS, folded deep into night \& black well of sources in-here is gone forth to meet in-there, \& we ARE bound below a sound or gesture; beneath distance, before time, at the foot of the silent forest, meet me here, I love you. (1968: 12)

That the Beat female literary community had more social, cultural and literary established restraints and impositions against which they had to rebel than the Beat male literary community is obvious. Not only did they have to transgress the capitalistic Cold War stagnation of American society at the time, but also the patriarchal and sexist paradigms in it and within their own Beat community at a cultural and social level regarding their position, and at a literary level regarding masculinist precepts of Romanic heroism, egotistical existential models and male experimental approaches to poetry. As many other proto-feminist avant-garde writers they occupied an ambivalent position, one of resisting and participating, a liminal state, as defined by Johnson and Grace (2002: 9). They participated in and resisted Beat experimental poetics by genderizing its experiential side, and by providing through their work a different version - a different beat, as the title of Peabody's anthology suggests - of the Beat voice and vision Ginsberg projected in his groundbreaking reading of "Howl" that marked the ethics and aesthetics of Beat life and art.

It is difficult to suggest taxonomical characteristics of Beat women poets' work that are not broken at some stage: they were many, their work was varied, vast and iconoclast. Critical studies generally takes them as a group without specifying 
geographical location; contrarily, my study looks closer to the practices and realities of New York Beat second-generation women's work and lives, trying to foreground patterns in their countercultural urban feminist geographies and contemporary avant-garde poetics. Their works and life acting as a second half of the twentieth-century meaningful, and quite often academically neglected, transitional bridge between first and second-wave feminisms in American society and literature.

Frost defines women's feminist avant-garde poetry in American literary history a hybrid poetics, hybridity being a particular feminist response to a "male avant-garde rhetoric of revolution" (2003: xii). Women poets of the New York Beat literary community shared what I would call a women's border poetics, that can be defined relying on Montefiore's third element of cohesion for female poetic traditions: the playful and contingent revision of, in this case, the tradition of masculinist Beat poetics - and by extension of American Romantics; and on feminist geographer Gillian Rose's concept of paradoxical space, since they simultaneously dwelled in and out of the communities, being present and absent, writing a public and private poetry that placed their voice and vision at border dwelling.

In order to counter the widely quoted words by Ginsberg, which reflect a general assumption about Beats, that said: "among the group of people we knew at the time, who were the [women] writers of such power as Kerouac or Burroughs? Were there any? I don't think so", it is necessary to work towards a revaluation of women poets' Beat voice and vision by reinscribing female Beatness in Beat discourse and literary history. As Johnson and Grace assert: "women were integral to Beat's development [... ] Women Beats alter and augment Beat's significations of nonconformity and wild individuality" (2002: 7). This paper tries to do so focusing on female poets and writers in the Beat New York bohemia of the 1950s and 1960s by validating their presence and visibility in literary and cultural space as readers, listeners and critics in the first section, as social agents and real historical bodies in the second section, and as writers and producers of cultural discourse in the third.

The creation of discursive and physical space for women is never late or redundant. Taking the recent publication of Cowen's poems as one proof, we can say that the Beat literary community is still expanding in the twenty-first century in order to reincorporate women authors, who by means of their work are remaking the contours of its cultural space: the definitions of being and writing Beat. 


\section{REFERENCES}

Castelao-Gómez, I. 2014. "Madre ausente, madre errante (o cómo ser madrespoetas): maternidad, creatividad y poesía en Mina Loy y Diane di Prima”. Malas. Eds. M. Almela Boix, M. García Lorenzo and H. Guzman. Madrid: UNED.

Charters, A., ed. 1992. The Portable Beat Reader. New York: Penguin.

Charters, A. 1993. "Beat Poetry and the San Francisco Poetry Renaissance". The Columbia History of American Poetry. Ed. J. Parini. New York: MJF Books. 581-604.

Cowen, E. 2014. Poems and Fragments. Ed. Tony Trigilio. Boise: Ahsahta Press.

Damon, M. 2002. "Revelations of Companionate Love; or, the Hurts of Women: Janine Pommy Vega's Poems to Fernando." Girls Who Wore Black: Women Writing of the Beat Generation. Eds. R. C. Johnson and N. M. Grace. New Brunswick: Rutgers. 205-227.

Damon, M. and I. Livingston, eds. 2009. Poetry and Cultural Studies. Chicago: University of Illinois Press.

Di Prima, D. 1990. Pieces of a Song: Selected Poems. San Francisco: City Lights.

Elkholy, S. N., ed. 2012. The Philosophy of the Beats. Lexington: University Press of Kentucky.

Friedman, A. L 1998. “'Being here as hard as I could': Beat Generation Women Writers". Discourse 20 (1): 229-244.

Frost, E. A. 2003. The Feminist Avant-Garde in American Poetry. Iowa City: U. of Iowa Press.

Grace, N. M. and R. C. Johnson, eds. 2004. Breaking the Rule of Cool: Interviewing and Reading Women Beat Writers. Jackson: University of Mississippi Press.

Grosz, E. 1992. "Bodies-Cities”. Sexuality and Space. Ed. B. Colomina. Princeton: Princeton Architectural Press. 241-253.

Grosz, E. 2000. "Woman, Chora, Dwelling”. Gender, Space, Architecture. Eds. J. Rendell, B. Penner and I. Borden. New York: Routledge. 210-221.

Hayden, D. 2000. “What Would a Non-Sexist City Be Like?' Gender, Space, Architecture. Eds. J. Rendell, B. Penner and I. Borden. New York: Routledge. 266-281.

Johnson, J. 1961. Come and Join the Dance. New York: Open Road.

Johnson, R. C. 2004. "Mapping Women Writers of the Beat Generation". Breaking the Rule of Cool: Interviewing and Reading Women Beat Writers. Eds. N. M. Grace and R. C. Johnson. Jackson: University of Mississippi Press. 3-41.

Johnson, R. C. and N. M. Grace, eds. 2002. Girls Who Wore Black: Women Writing of the Beat Generation. New Brunswick: Rutgers. 
Knight, B. 1996. Women of the Beat Generation: The Writers, Artists and Muses of the Heart of a Revolution. Berkeley: Conari Press.

Massey, D. 1994. Space, Place and Gender. Cambridge: Blackwell.

McDowell, L 1999. Gender, Identity and Place: Understanding Feminist Geographies. London: Polity Press.

Montefiore, J. 1994. Feminism and Poetry. London: Pandora.

Peabody, R, ed. 1997. A Different Beat: Writings by Women of the Beat Generation. London: Serpent's Tail.

Pegrum, A. M., ed. 2015. Beat attitude: Antología de mujeres poetas de la generación beat. Madrid: Bartleby Editores.

Pommy-Vega, J. 1968. Poems to Fernando. San Francisco: City Lights Books.

Quinn, R. G. 2012. "The Laugh of the Revolutionary: Diane di Prima, French Feminist Philosophy and the Contemporary Cult of the Beat Heroine". The Philosophy of the Beats. Ed. S. N. Elkholy. Lexington: University Press of Kentucky. 19-32.

Rendell, J., Penner, B. and I. Borden, eds. 2000. Gender, Space, Architecture. New York: Routledge.

Rendell, J. 2002. The Pursuit of Pleasure. London: The Athlone Press.

Rose, G. 1993. Feminism and Geography: The Limits of Geographical Knowledge. London: Polity Press.

Wilson, E. 1992. The Sphinx in the City: Urban Life, the Control of Disorder, and Women. Berkeley: University of California Press.

Wolff, J. 1995. Resident Alien: Feminist Cultural Criticism. New Haven: Yale UP. 